\title{
Analisis Kompensasi Daya Reaktif Motor Induksi 3 Fasa Saat Beban Puncak Pada PT. Semen Tonasa Unit 4
}

\author{
Yusril Iksan 1), Bakhtiar, S.T, M.T 2), Ruslan L, S.T, M.T 3 ${ }^{\text {), }}$ \\ ${ }^{1}$ Jurusan Teknik Elektro, Politeknik Negeri Ujung Pandang \\ yusriliksan3984@gmail.com \\ ${ }^{2}$ Jurusan Teknik Elektro, Politeknik Negeri Ujung Pandang \\ bakhtiar.poltekup@gmail.com \\ ${ }^{3}$ Jurusan Teknik Elektro, Politeknik Negeri Ujung Pandang \\ ruslanlausu@gmail.com
}

\begin{abstract}
Abstrak
Analisis kompensasi daya reaktif motor induksi 3 fasa saat beban puncak adalah sebuah penelitian untuk mengetahui; (1) besar kompensasi daya reaktif yang diperlukan untuk memperbaiki faktor daya motor induksi 3 fasa saat beban puncak ; (2) besar pemasangan kapasitor bank untuk mencapai nilai faktor daya perbaikan; dan (3) membandingkan perubahan sebelum dan setelah dilakukannya perbaikan faktor daya menjadi 0,90 yang dilaksanakan di PT. Semen Tonasa Uni 4. Teknik pengumpulan data pada penelitian ini dilakukan dengan pengumpulan data primer dengan melakukan wawancara dengan pihak-pihak terkait penelitian dan sekunder atau melakukan penelusuran data terkait penelitian, selanjutnya dilakukan analisis data, lalu membuat simulasi untuk membandingkan hasil analisis dan hasil simulasi. Adapun hasil penelitian menunjukkan hasil sebagai berikut ; (1) Besar kompensasi daya reaktif $\left(\mathrm{Q}_{\mathrm{c}}\right)$ diperoleh berdasarkan selisih dari daya reaktif sebelum perbaikan faktor daya $\left(\mathrm{Q}_{b}\right)$ dengan daya reaktif setelah perbaikan $\left(\mathrm{Q}_{\mathrm{t}}\right)$; (2) Besar kapasitor yang digunakan pada kompensasi daya reaktif berdasarkan nilai standar kapasitor yang ada di pasaran. Semakin besar nilai kompensasi daya reaktif yang ditimbulkan maka nilai kapasitor yang dibutuhkan dalam perbaikan faktor daya akan semakin besar ; dan (3) Setelah faktor daya diseragamkan nilai perbaikannya, maka besar arus beban menjadi semakin kecil dan nilai pasokan daya MVA menjadi semakin kecil.
\end{abstract}

Kata Kunci: daya reaktif, beban puncak, faktor daya, kapasitor bank, simulasi

\section{PENDAHULUAN}

Setiap pabrik/industri memiliki beban induktif yang besar dalam proses produksinya. Maka dari itu akan membutuhkan daya reaktif yang begitu besar pula, sedangkan yang tersedia dalam pembangkitan tenaga listrik suplai daya aktif dan daya reaktif dimana kedua jenis daya ini saling mempengaruhi dengan lainnya. Salah satu cara dalam mengatasi daya reaktif ini adalah dengan menyediakan beban yang bersifat kapasitif, atau dengan melakukan pemasangan kapasitor. Kapasitor akan menghasilkan daya reaktif yang diperlukan oleh beban induktif. Sehingga akan mengurangi segala rugi-rugi daya listrik yang terjadi.

Salah satu perusahaan industri yang memiliki beban induktif yang besar adalah PT. Semen Tonasa utamanya pada unit 4. Pada unit 4 ini terdapat 11 buah motor yang dilayani oleh 2 sumber listrik utama yakni suplay daya dari pembangkit sendiri dan juga suplay daya dari PLN. Motor-motor yang digunakan adalah motor-motor berukuran besar sehingga membutuhkan daya reaktif yang besar pula saat beroperasi. Besarnya daya reaktif yang digunakan berdampak pada menurunnya nilai faktor daya pada area tersebut. Bahkan ditemukan pada beberapa motor-motor listrik, nilai faktor dayanya 0,68 pada kondisi beban puncak (rentan waktu pukul 17.00 - 22.00).

Tujuan penelitian ini meliputi: (1) Menganalisis besar kompensasi daya reaktif yang diperlukan untuk memperbaiki faktor daya.; (2) Menganalisis besar pemasangan kapasitor bank untuk mencapai nilai faktor daya perbaikan; (3) Dapat membandingkan perubahan sebelum dan setelah dilakukannya perbaikan faktor daya menjadi 0,90.

Adapun kegunaan dalam penelitian ini adalah sebagai bahan pembelajaran dalam upaya menambah pengetahuan dan wawasan yang lebih luas. Selain itu, juga sebagai bahan informasi atau bahan acuan bagi peneliti selanjutnya dalam skala yang lebih luas dan kompleks yang berkaitan dengan judul ini 


\section{KAJIAN LITERATUR}

A. Motor Induksi

Motor induksi merupakan motor listrik arus bolak balik (AC) yang paling luas digunakan. Penamaannya berasal dari kenyataan bahwa motor ini bekerja berdasarkan induksi medan magnet stator ke statornya, dimana arus rotor motor ini bukan diperoleh dari sumber tertentu, tetapi merupakan arus yang terinduksi sebagai akibat adanya perbedaan relatif antara putaran rotor dengan medan putar (rotating magnetic field) yang dihasilkan oleh arus stator.

\section{B. Daya}

Daya merupakan jumlah energi listrik tiap satuan waktu. Daya listrik dibagi menjadi tiga, yaitu daya aktif, daya reaktif dan daya semu. Berikut adalah penjelasan dari ketiga daya tersebut. Ketiga daya ini digambarkan dengan segitiga daya. Gambar 1 adalah gambar segitiga daya.

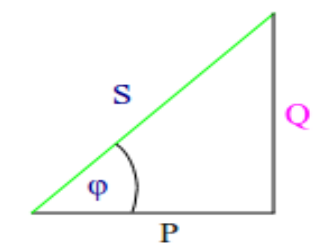

Gambar 1. Segitiga Daya

\section{B.1 Daya Aktif}

Daya aktif adalah daya yang sebenarnya digunakan oleh konsumen. Daya aktif memiliki satuan Watt.

a. Daya Aktif 1 Phasa

$$
\mathrm{P}=V_{l n} . \mathrm{I} \cdot \cos \varphi
$$

b. Daya Aktif 3 Phasa

$$
\mathrm{P}=\sqrt{3} \cdot V_{l l} \cdot \mathrm{I} \cdot \cos \varphi
$$

\section{B.2 Daya Reaktif}

Daya reaktif merupakan daya yang digunakan untuk menghasilkan medan magnet. Daya aktif diberi simbol Q, sedangkan satuan daya reaktif adalah Var (Volt Ampere Reactive).

a. Daya Reaktif 1 Phasa

$$
\mathrm{Q}=V_{l n} . \mathrm{I} \cdot \sin \varphi
$$

b. Daya Reaktif 3 Phasa

$$
\mathrm{Q}=\sqrt{3} \cdot V_{l l} \cdot \mathrm{I} \cdot \sin \varphi
$$

\section{B.3 Daya Semu}

Daya semu merupakan daya yang dibangkitkan oleh generator pada sistem pembangkit listrik. Daya semu diberi simbol S dan memiliki satuan VA (Volt Ampere).

a. Daya Semu 1 Phasa

$$
\mathrm{S}=V_{l n} . \mathrm{I}
$$

b. Daya Semu 3 Phasa

$$
\mathrm{S}=\sqrt{3} \cdot V_{l l} \cdot \mathrm{I}
$$

C. Faktor Daya

Faktor daya merupakan cosinus dari beda sudut fasa antara arus dan tegangan. Faktor daya disimbolkan dengan $\cos \varphi$ dan mempunyai rentang nilai antara 0 sampai 1 . Semakin mendekati 1 maka nilai faktor daya akan semakin baik. Kemudian untuk mencari nilai faktor daya dapat dilakukan dengan membagi daya aktif (P) dengan daya semu (S). Faktor daya dibagi menjadi dua yaitu faktor daya tertinggal (lagging) dan faktor daya mendahului (leading).

\section{1. Perbaikan Faktor Daya}

Untuk perbaikan faktor daya adalah meningkatkan nilai dari $\operatorname{Cos} \varphi_{1}$ menjadi $\operatorname{Cos} \varphi_{2}$ dengan tingkat distorsi yang rendah dan tidak terjadi resonansi pada impedansi bus-bus utama. Berdasarkan atas pengukuran saat pemakaian normal dan pemakaian beban puncak dapat ditentukan kebutuhan daya aktif dan daya reaktifnya :

$$
\operatorname{Cos} \varphi(\mathrm{pf})=\frac{\mathrm{P}}{s}=\frac{\mathrm{VI} \operatorname{Cos} \varphi}{\mathrm{V} \mathrm{I}}
$$

V I Cos $\varphi$ adalah total daya aktif (P total) pada saat operasional, maka:

$$
\begin{gathered}
\text { Daya Reaktif }=\sqrt{\mathrm{kVA}^{2}-\mathrm{kW}^{2}}=\mathrm{kVA} \operatorname{Sin} \varphi \\
=\mathrm{kW} \operatorname{Tan} \varphi \\
\text { Daya Semu }=\sqrt{\mathrm{kVAR}^{2}+\mathrm{kW}^{2}}=\frac{\mathrm{kW}}{\operatorname{Cos} \varphi}
\end{gathered}
$$

Untuk meningkatkan harga $\operatorname{Cos} \varphi_{2}$ mendekati harga ideal yaitu 1 (Unity Power faktor). Dalam hal ini, dengan melihat karakteristik beban yang fluktuatif maka target perbaikan faktor daya adalah dari $\operatorname{Cos} \varphi_{1}$ menjadi $\operatorname{Cos} \varphi_{2}$. Sehingga kebutuhan daya reaktifnya akan berubah menjadi:

$$
\begin{aligned}
& \mathrm{Q}_{\mathrm{b}}=\mathrm{P} \operatorname{Tan} \varphi_{1} \\
& \mathrm{Q}_{\mathrm{t}}=\mathrm{P} \operatorname{Tan} \varphi_{2}
\end{aligned}
$$

Sehingga :

$$
\begin{aligned}
\mathrm{Q}_{\mathrm{c}} & =\mathrm{Q}_{\mathrm{b}}-\mathrm{Q}_{\mathrm{t}} \\
\mathrm{C} & =\frac{\mathrm{Q}_{\mathrm{c}}}{2 \pi f \mathrm{~V}^{2}}
\end{aligned}
$$


D. Capacitor Bank Sebagai Perbaikan Faktor Daya

\section{D.1 Pengertian Capacitor Bank}

Capacitor bank adalah rangkaian yang terdiri dari beberapa unit kapasitor. Kapasitas unit kapasitor menyatakan besar daya reaktif nominal yang dihasilkan pada tegangan dan frekuensi nominal, dinyatakan dalam satuan dasar VAR.

\section{D.2 Prinsip Kerja Capacitor Bank}

Kapasitor yang akan digunakan untuk memperbesar pf dipasang paralel dengan rangkaian beban. Bila rangkaian itu diberi tegangan maka elektron akan mengalir masuk ke kapasitor. Pada saat kapasitor penuh dengan muatan elektron maka tegangan akan berubah. Kemudian elektron akan ke luar dari kapasitor dan mengalir ke dalam rangkaian yang memerlukannya dengan demikian pada saat itu kapasitor membangkitkan daya reaktif. Bila tegangan yang berubah itu kembali normal (tetap) maka kapasitor akan menyimpan kembali elektron. Pada saat kapasitor mengeluarkan elektron (Ic) berarti sama juga kapasitor menyuplai daya reaktif ke beban. Karena beban bersifat induktif (+) sedangkan daya reaktif bersifat kapasitor (-) akibatnya daya reaktif yang berlaku menjadi kecil.

\section{D.3 Perancangan Instalasi Capacitor Bank}

Cara pemasangan instalasi capacitor bank dapat dibagi menjadi 3 bagian seperti gambar 3 yaitu: global compensation, individual compensation dan group compensation.

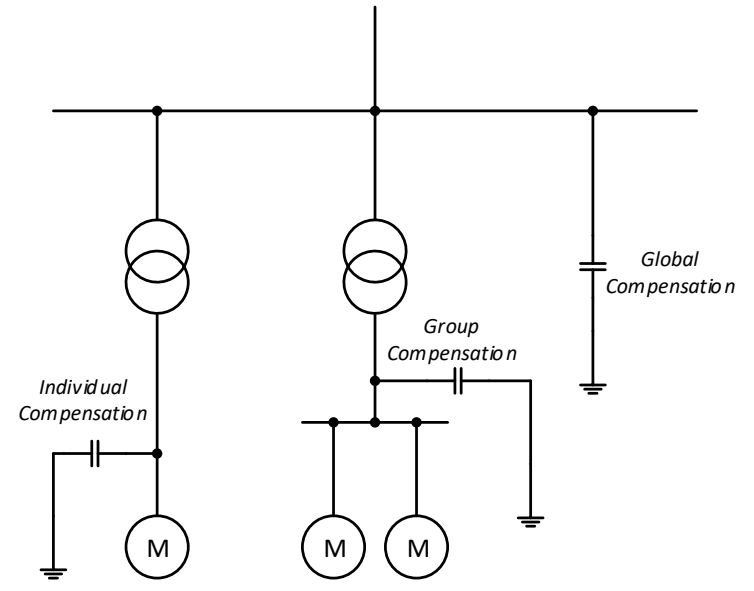

Gambar 2. Perancangan Instalasi Capacitor Bank

Pemilihan nilai capacitor bank (shunt capacitor) yang efektif digunakan pada suatu jaringan kelistrikan mengacu pada tabel 1 .
Tabel 1. Acuan Nilai Penggunaan Kapasitor

\begin{tabular}{llll}
\hline $\begin{array}{l}\text { Daya } \\
\text { Tumpuk } \\
\begin{array}{l}\text { Kapasitor } \\
\text { (kVAR) }\end{array}\end{array}$ & $\begin{array}{l}\text { Jumlah } \\
\text { Etep } \\
\text { Efektif }\end{array}$ & $\begin{array}{l}\text { Daya/Step } \\
\text { (kVAR) }\end{array}$ & Kode Kapasitor \\
100 & 6 & 10 & 52419 \\
150 & 4 & 25 & $52419+52421$ \\
200 & 5 & 25 & $52420+52421$ \\
270 & 5 & 30 & $2 \times 52421$ \\
300 & 6 & 30 & $3 \times 52421$ \\
375 & 8 & 35 & $52420+52421$ \\
400 & 8 & 50 & 52422 \\
450 & 9 & 50 & 52422 \\
500 & 10 & 50 & 52422 \\
600 & 10 & 60 & 52423 \\
700 & 8 & 50 & 52422 \\
800 & 9 & 50 & 52422 \\
900 & 8 & 60 & 52423 \\
1000 & 10 & 100 & $2 \times 52422$ \\
1100 & 11 & 100 & $3 \times 52422$ \\
1200 & 12 & 100 & $4 \times 52422$ \\
\hline
\end{tabular}

E. Beban Puncak (Peak Load)

Beban Puncak (Pmax) adalah nilai terbesar dari pembebanan sesaat pada suatu interval demand tertentu. Untuk dapat memperjelas pengertian mengenai Demand (D), Maximum Demand (Dmax) dan Beban Puncak (Pmax) dapat dilihat pada Gambar 3.

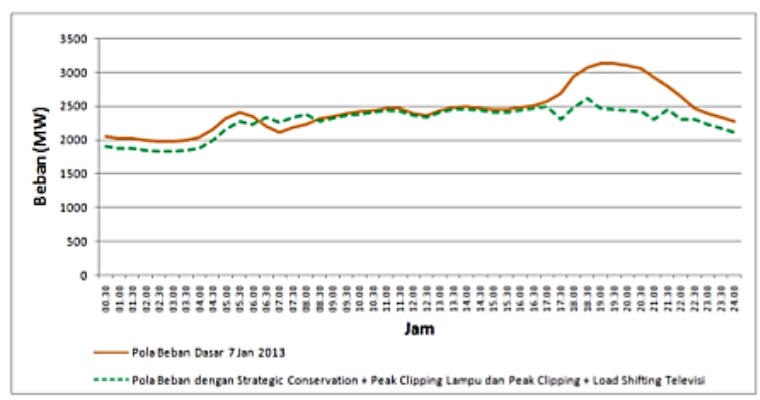

Gambar 3. Perubahan Kebutuhan Maksimum Terhadap Waktu

Interval Demand $\quad: \mathrm{T}=24 \mathrm{jam}$

Demand $=$ Pav $\quad: \mathrm{D}=27 \mathrm{~kW}$

Maximum Demand $\quad$ : Dmax, 1 jam $=95$

$\mathrm{kW}$

Beban Puncak $\quad:$ Pmax $=100 \mathrm{~kW}$

E. Program DIgSILENT PowerFactory

DIgSILENT Nama singkatan dari "DIgital SImuLation and Electrical NeTwork calculation program". DIgSILENT Versi 15.1 adalah perangkat lunak analisis sistem tenaga 
yang pertama di dunia yang terintegrasi dengan grafis antar muka satu baris, diagram satu baris interaktif, juga termasuk fungsi menggambar, kemampuan mengedit dan semua relevan statis dan dinamis fitur perhitungan.

Salah satu fungsi yang tersedia dalam DIgSILENT PowerFactory seperti analisis aliran beban/loadflow analysis yang mana berkaitan dengan pembahasan kompensasi daya reaktif, parameter yang digunakan adalah parameter yang digunakan seperti nilai daya aktif, daya reaktif, daya semu, arus, tegangan serta nilai kapasiansi yang nantinya digunakan untuk kompensasi daya reaktif.

\section{METODE PENELITIAN}

Metode teknik pengumpulan data pada penelitian ini dilakukan dengan pengumpulan data primer dengan melakukan wawancara dengan pihak-pihak terkait penelitian dan sekunder atau melakukan penelusuran data terkait penelitian, selanjutnya dilakukan analisis data, lalu kemudian membuat simulasi untuk membandingkan hasil analisis perhitungan dengan simulasi pada program.

\section{HASIL DAN PEMBAHASAN}

A. Sistem Kelistrikan PT. Semen Tonasa Unit 4 Cabang $400 \mathrm{~V}$

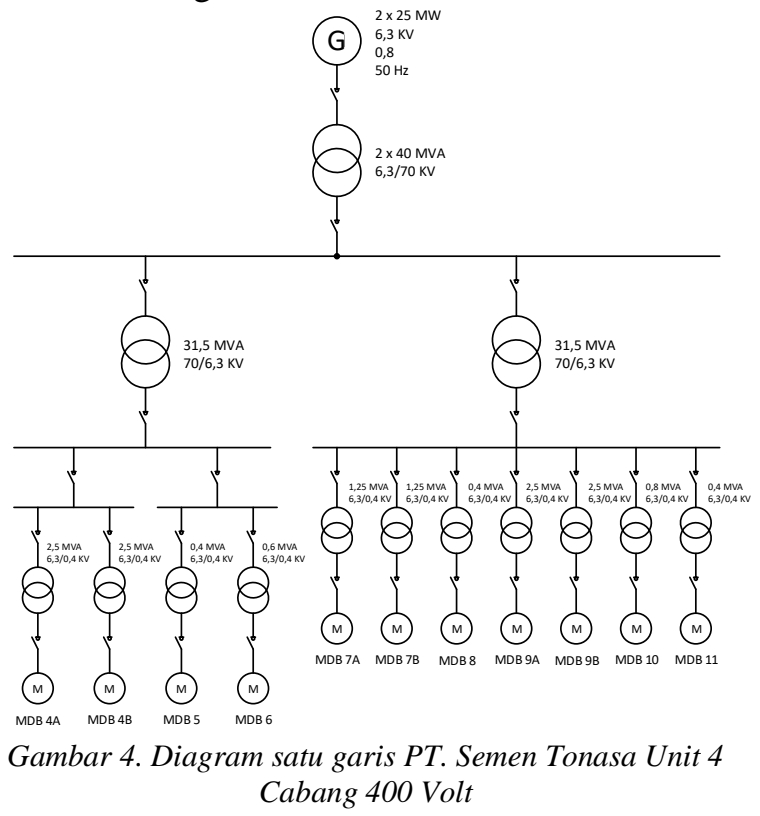

Daya yang digunakan dalam proses produksi di PT. Semen Tonasa Unit IV Cabang 400 Volt untuk 11 motor induksi pada Gambar 4. disuplai dari pembangkit listrik Biringkasi yang merupakan pembangkit sendiri degan daya terpasang $50 \mathrm{MW}$ dengan dua buah trafo yang masing-masing berkapasitas 25 MW untuk setiap unit. Untuk pengiriman daya dari pembangkit ke Unit 4 terlebih dahulu menaikkan tegangan dari 6,3 menjadi $70 \mathrm{KV}$ melalui 2 buah trafo step up yang masingmasing berkapasitas 40 MVA pada GI pembangkit. Tegangan $70 \mathrm{KV}$ ditransmisikan ke GI PT. Semen Tonasa Unit IV lalu diturunkan tegangannya menjadi $6,3 \mathrm{KV}$ dengan trafo step down, dan tegangan disuplai ke 3 buah group yang terdiri dari 11 buah motor induksi. Namun sebelum masuk ke motor, terlebih dahulu tegangan di turunkan menjadi 400 Volt dengan menggunakan trafo step down, dan setiap motor induksi memiliki trafo tersendiri.

B. Motor Induksi 3 Fasa pada Cabang 400 Volt

Nilai PF untuk setiap motor dapat dihitung sebagi berikut. Besar PF pada MDB 4A:

$$
\operatorname{Cos} \varphi_{1} \quad(\mathrm{PF})=\frac{\mathrm{P}}{S}=\frac{1,138}{1,674}=0,68
$$

Dengan mensubtitusikan nilai PF di atas ke persamaan berikut maka diperoleh:

$$
\varphi_{1}=\operatorname{Cos}^{-} 0,68=47,156^{\circ}
$$

Maka besar MVAR yaitu:

$$
\begin{aligned}
\mathrm{Q}_{\mathrm{b}}=\mathrm{P} \operatorname{Tan} \varphi_{1} & =1,138 \times \tan 47,156^{\circ} \\
& =1,227 \mathrm{MVAR}
\end{aligned}
$$

Dengan menggunakan cara yang sama untuk tiap motor maka diperoleh hasil sebagaimana

\begin{tabular}{|c|c|c|c|c|c|c|c|}
\hline No. & Lokasi & $\begin{array}{c}\text { Tegangan } \\
\text { (V) }\end{array}$ & $\begin{array}{l}\text { Arus } \\
\text { (A) }\end{array}$ & $\underset{(\mathbf{M W})}{\mathbf{P}}$ & $\stackrel{\text { S }}{(\mathbf{M V A})}$ & $\mathbf{P F}$ & $\begin{array}{c}\text { Qb } \\
\text { (MVAR }\end{array}$ \\
\hline 1 & $\begin{array}{c}\text { MDB 4A } \\
\text { (Raw Mill 1) }\end{array}$ & 400 & 2461 & 1,138 & 1,674 & 0,68 & 1,227 \\
\hline 2 & $\begin{array}{c}\text { MDB 4B } \\
\text { (Raw Mill 2) }\end{array}$ & 400 & 2461 & 1,138 & 1,674 & 0,68 & 1,227 \\
\hline 3 & $\begin{array}{c}\text { MDB 5 } \\
\text { (Raw Mill 2) }\end{array}$ & 400 & 388 & 0,219 & 0,264 & 0,83 & 0,147 \\
\hline 4 & $\begin{array}{l}\text { MDB } 6 \\
\text { (Raw Mill } \\
\text { Transport) }\end{array}$ & 400 & 543 & 0,321 & 0,370 & 0,87 & 0,182 \\
\hline 5 & $\begin{array}{l}\text { MDB 7A } \\
\text { (Blending } \\
\text { Silo) }\end{array}$ & 400 & 1320 & 0,709 & 0,897 & 0,79 & 0,550 \\
\hline 6 & $\begin{array}{l}\text { MDB 7B } \\
\text { (Blending } \\
\text { Silo) }\end{array}$ & 400 & 1320 & 0,709 & 0,897 & 0,79 & 0,550 \\
\hline 7 & $\begin{array}{c}\text { MDB } 8 \\
\text { (Kiln) }\end{array}$ & 400 & 385 & 0,220 & 0,262 & 0,84 & 0,142 \\
\hline 8 & $\begin{array}{c}\text { MDB 9A } \\
\text { (Clinker } \\
\text { Cooler) }\end{array}$ & 400 & 2896 & 1,615 & 1,970 & 0,82 & 1,127 \\
\hline 9 & $\begin{array}{c}\text { MDB 9B } \\
\text { (Clinker } \\
\text { Cooler) }\end{array}$ & 400 & 2896 & 1,615 & 1,970 & 0,82 & 1,127 \\
\hline
\end{tabular}
pada tabel 3 .

Tabel 2. Data Kondisi Pembebanan pada Beban Puncak (Pukul 17.00-22.00) 


\begin{tabular}{|c|c|c|c|c|c|c|c|}
\hline & & 400 & 779 & 0,392 & 0,530 & 0,74 & 0,356 \\
\hline & $\begin{array}{c}\text { MDB } 11 \\
\text { (Precipitator) }\end{array}$ & 400 & 323 & 0,169 & 0,220 & 0,76 & \\
\hline
\end{tabular}

C. Menjadikan $\mathrm{PF}=0,90$

Dengan mengacu pada nilai-nilai saat beban puncak maka hasil yang diperoleh setelah faktor daya $(\mathrm{PF}=0,90)$ untuk motor MDB $4 \mathrm{~A}$ adalah dengan menggunakan beberapa persamaan yaitu sebagai berikut.

$$
\begin{aligned}
&-\mathrm{PF}=\frac{\mathrm{P}}{S} \\
& \mathrm{~S}=\frac{\mathrm{P}}{\mathrm{PF}} \\
& \mathrm{S}=\frac{1,138}{0,90} \\
& \mathrm{~S}=1,264 \mathrm{MVA} \\
&-\quad \mathrm{S}=\sqrt{3} \cdot \mathrm{V} \cdot \mathrm{I} \\
& \mathrm{I}=\frac{\mathrm{S}}{\sqrt{3} \cdot \mathrm{V}} \\
& \mathrm{I}=\frac{1264000}{\sqrt{3} \cdot 400} \\
& \mathrm{I}=1.824 \mathrm{~A} \\
& \varphi_{2}=\mathrm{Cos}^{-} 0,90=25,842^{\circ} \\
&-\quad \mathrm{Q}_{t}=\mathrm{P} . \text { Tan } \varphi_{2}= \\
& 1,138 \times \text { Tan } 25,842^{\circ}=0,551 \mathrm{MVAR} \\
& \text { Dengan menggunakan cara yang sama } \\
& \text { untuk tiap motor maka diperoleh hasil } \\
& \text { sebagaimana pada tabel } 3 .
\end{aligned}
$$

\begin{tabular}{|c|c|c|c|c|c|c|c|}
\hline No. & Lokasi & $\begin{array}{c}\text { Teganga } \\
\text { n (V) }\end{array}$ & $\begin{array}{c}\text { Arus } \\
\text { (A) }\end{array}$ & $\underset{(\mathbf{M W})}{\mathbf{P}}$ & $\begin{array}{c}\text { S } \\
\text { (MVA } \\
\text { ) }\end{array}$ & PF & $\begin{array}{c}\mathbf{Q}_{\mathbf{t}} \\
(\mathbf{M V A} \\
\mathbf{R})\end{array}$ \\
\hline 1 & $\begin{array}{c}\text { MDB 4A } \\
\text { (Raw Mill } \\
\text { 1) }\end{array}$ & 400 & 1824 & 1,138 & 1,264 & 0,90 & 0,551 \\
\hline 2 & $\begin{array}{l}\text { MDB 4B } \\
\text { (Raw Mill } \\
\text { 2) }\end{array}$ & 400 & 1824 & 1,138 & 1,264 & 0,90 & 0,551 \\
\hline 3 & $\begin{array}{l}\text { MDB 5 } \\
\text { (Raw Mill } \\
\text { 2) }\end{array}$ & 400 & 351 & 0,219 & 0,243 & 0,90 & 0,106 \\
\hline 4 & $\begin{array}{c}\text { MDB } 6 \\
\text { (Raw Mill } \\
\text { Transport) }\end{array}$ & 400 & 515 & 0,321 & 0,357 & 0,90 & 0,155 \\
\hline 5 & $\begin{array}{l}\text { MDB 7A } \\
\text { (Blending } \\
\text { Silo) }\end{array}$ & 400 & 1137 & 0,709 & 0,788 & 0,90 & 0,343 \\
\hline 6 & $\begin{array}{l}\text { MDB 7B } \\
\text { (Blending } \\
\text { Silo) }\end{array}$ & 400 & 1137 & 0,709 & 0,788 & 0,90 & 0,343 \\
\hline 7 & $\begin{array}{c}\text { MDB } 8 \\
\text { (Kiln) }\end{array}$ & 400 & 352 & 0,220 & 0,244 & 0,90 & 0,107 \\
\hline
\end{tabular}

Tabel 3. Hasil pada $P F=0,90$
MDB 9A

$8 \quad$ (Clinker $\quad 400 \quad 2589 \quad 1,615 \quad 1,794 \quad 0,90 \quad 0,782$

Cooler)

MDB 9B

9 (Clinker $400 \quad 2589 \quad 1,615 \quad 1,794 \quad 0,90 \quad 0,782$

Cooler)

MDB 10

$10 \quad \begin{array}{lllllll}\text { Coal } & 400 & 629 & 0,392 & 0,436 & 0,90 & 0,189\end{array}$

Mill)

MDB 11

11 (Precipitat $400 \quad 270 \quad 0,169 \quad 0,187 \quad 0,90 \quad 0,082$ or)

Apabila dilihat dari perbandingan segitiga daya antara nilai $\cos \varphi$ dan nilai daya reaktif $Q$ antara sebelum perbaikan dan setelah perbaikan maka akan tampak seperti pada gambar 8 .

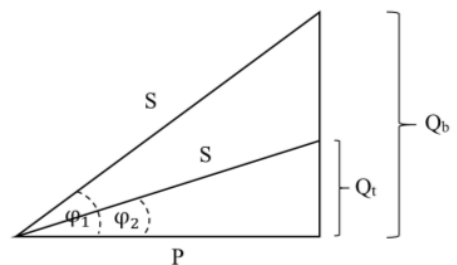

Gambar 5. Perbandingan Segitiga Daya Sebelum dan Sesudah Perbaikan

\begin{tabular}{|c|c|c|c|c|c|c|}
\hline \multirow{3}{*}{ No. } & \multirow{3}{*}{ Lokasi } & \multirow{3}{*}{$\begin{array}{c}\text { Teganga } \\
\mathbf{n}(\mathbf{V})\end{array}$} & \multirow{2}{*}{$\begin{array}{c}\text { Qb } \\
\text { MVAR }\end{array}$} & $\mathbf{Q t}$ & \multicolumn{2}{|l|}{ Qc } \\
\hline & & & & (MVAR & (MVAF & $\mathrm{C}(\boldsymbol{\mu} \mathrm{F})$ \\
\hline & & & ) & ) & ) & \\
\hline 1 & $\begin{array}{c}\text { MDB 4A } \\
\text { (Raw Mill } \\
\text { 1) }\end{array}$ & 400 & 1,227 & 0,551 & 0,676 & 13500 \\
\hline 2 & $\begin{array}{c}\text { MDB 4B } \\
\text { (Raw Mill } \\
\text { 2) }\end{array}$ & 400 & 1,227 & 0,551 & 0,676 & 13500 \\
\hline 3 & $\begin{array}{l}\text { MDB 5 } \\
\text { (Raw Mill } \\
\text { 2) }\end{array}$ & 400 & 0,147 & 0,106 & 0,041 & 800 \\
\hline 4 & $\begin{array}{c}\text { MDB } 6 \\
\text { (Raw Mill } \\
\text { Transport) }\end{array}$ & 400 & 0,182 & 0,155 & 0,027 & 500 \\
\hline
\end{tabular}

Kompensasi daya reaktif pada MDB 4A yaitu sebagai berikut.

$$
\begin{aligned}
\mathrm{Q}_{\mathrm{c}}=\mathrm{Q}_{\mathrm{b}}-\mathrm{Q}_{\mathrm{t}} & =1,227-0,551 \\
& =0,676 \text { MVAR }
\end{aligned}
$$

Adapun data yang digunakan untuk penjabaran prosesnya berdasarkan dari MDB $4 \mathrm{~A}$.

$$
\begin{aligned}
\mathrm{C}=\frac{\mathrm{Q}_{\mathrm{c}}}{2 \pi f \mathrm{~V}^{2}}= & \frac{676.000}{2 \times 3,14 \times 50 \times 400^{2}} \\
& =0,0135 \mathrm{~F}=13.500 \mu \mathrm{F}
\end{aligned}
$$

Dengan menggunakan cara yang sama untuk setiap datanya, sehingga diperoleh nilainilai kompensasi daya reaktif setelah perbaikan $\left(\mathrm{Q}_{\mathrm{c}}\right.$ dan besar nilai kapasitor yang terpasang nantinya pada tabel 4 .

Tabel 4. Kompensasi Reaktif pada $\mathrm{PF}=0,90$ 
MDB 7A

5 (Blending $400 \quad 0,550 \quad 0,343 \quad 0,207 \quad 4100$ Silo)

MDB 7B

6 (Blending $400 \quad 0,550 \quad 0,343 \quad 0,207 \quad 4100$

Silo)

$7 \begin{array}{cccccc}\text { MDB 8 } & 400 & 0,142 & 0,107 & 0,035 & 600\end{array}$

MDB 9A

$8 \quad$ (Clinker $400 \quad 1,127 \quad 0,782 \quad 0,345 \quad 6900$

Cooler)

MDB 9B

$9 \quad$ (Clinker $400 \quad 1,127 \quad 0,782 \quad 0,345 \quad 6900$

Cooler)

$10 \begin{gathered}\text { MDB 10 } \\ \text { Coal Mill }\end{gathered} 400 \quad 0,356 \quad 0,189 \quad 0,167 \quad 3300$

MDB 11

11 (Precipitat $400 \quad 0,145 \quad 0,082 \quad 0,063 \quad 1300$ or)

Berdasarkan nilai kapasitansi di atas maka dapat ditetapkan besar pemasangan kapsitor dengan mengacu pada standar nilai kapasitor pada tabel 1 . Maka besar kapasitor bank (shunt capasitor) yang digunakan untuk tiap motor induksi 3 fasa adalah seperti pada tabel 5.

Tabel 5. Nilai Pemasangan Kapasitor untuk $\mathrm{PF}=0,90$

\begin{tabular}{|c|c|c|c|c|c|c|}
\hline No. & Lokasi & $\begin{array}{c}\text { Qc } \\
\text { (MVAR) }\end{array}$ & $\begin{array}{c}\text { Daya } \\
\text { Tumpuk } \\
\text { (Kapasitor } \\
\text { (KVAR) }\end{array}$ & $\begin{array}{l}\text { Jumlah } \\
\text { Step } \\
\text { Efektif ( }\end{array}$ & $\begin{array}{l}\text { Daya/ } \\
\text { Step } \\
\text { (KVAR) }\end{array}$ & $\begin{array}{c}\text { Jumlah } \\
\text { Step }\end{array}$ \\
\hline 1 & $\begin{array}{c}\text { MDB 4A } \\
\text { (Raw Mill } \\
\text { 1) }\end{array}$ & 0,676 & 1000 & 10 & 100 & 7 \\
\hline 2 & $\begin{array}{l}\text { MDB 4B } \\
\text { (Raw Mill } \\
\text { 2) }\end{array}$ & 0,676 & 1000 & 10 & 100 & 7 \\
\hline 3 & $\begin{array}{l}\text { MDB 5 } \\
\text { (Raw Mill } \\
\text { 2) }\end{array}$ & 0,041 & 100 & 6 & 10 & 5 \\
\hline 4 & $\begin{array}{c}\text { MDB } 6 \\
\text { (Raw Mill } \\
\text { Transport) }\end{array}$ & 0,027 & 100 & 6 & 10 & 3 \\
\hline 5 & $\begin{array}{l}\text { MDB 7A } \\
\text { (Blending } \\
\text { Silo) }\end{array}$ & 0,207 & 375 & 8 & 35 & 7 \\
\hline 6 & $\begin{array}{l}\text { MDB 7B } \\
\text { (Blending } \\
\text { Silo) }\end{array}$ & 0,207 & 375 & 8 & 35 & 7 \\
\hline 7 & $\begin{array}{c}\text { MDB } 8 \\
\text { (Kiln) }\end{array}$ & 0,035 & 100 & 6 & 10 & 5 \\
\hline 8 & $\begin{array}{l}\text { MDB 9A } \\
\text { (Clinker } \\
\text { Cooler) }\end{array}$ & 0,345 & 500 & 10 & 50 & 8 \\
\hline 9 & $\begin{array}{c}\text { MDB 9B } \\
\text { (Clinker } \\
\text { Cooler) }\end{array}$ & 0,345 & 500 & 10 & 50 & 8 \\
\hline 10 & $\begin{array}{l}\text { MDB 10 } \\
\text { (Coal Mill) } \\
\text { MDB 11 }\end{array}$ & 0,167 & 375 & 8 & 35 & 5 \\
\hline 11 & $\begin{array}{c}\text { (Precipitator } \\
\text { ) }\end{array}$ & 0,063 & 150 & 4 & 25 & 3 \\
\hline
\end{tabular}

D. $\quad$ Simulasi DigSilent PowerFactory 15.1

Sebelum melakukan simulasi terlebih dahulu membuat pemodelan untuk diagram satu garis PT. Semen Tonas Unit 4 Cabang 400 Volt ke dalam software DigSilent PowerFactory 15.1. Gambar 6 adalah gambar pemodelan yang telah dibuat menggunakan data dari kondisi real untuk nilai-nilai input yang dibutuhkan.

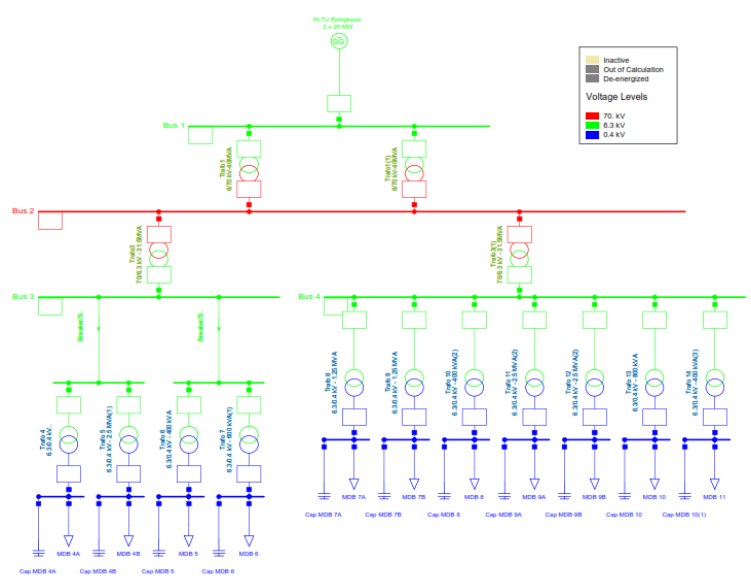

Gambar 6. Pemodelan pada DigSilent PowerFactory 15.1

a. Simulasi Faktor Daya Sebelum Perbaikan

Selanjutnya dilakukan simulasi pada kondisi sebelum perbaikan faktor daya. Berikut gambar 7 adalah gambar pada bagian pembebanan.

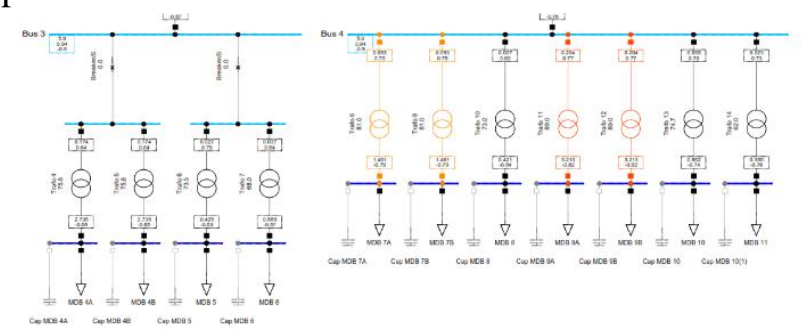

Gambar 7. Hasil Simulasi Sebelum Perbaikan Faktor Daya

b. Simulasi pada $\mathrm{PF}=0,90$

Simulasi ini dilakukan dengan memasukkan nilai kapasitor berdasarkan hasil dari pemilihan kapasitor dengan pendakatan nilai kompensasi reaktif pada nilai faktor daya $(\mathrm{PF}=0,90)$. Berikut hasil simulasi yang diperoleh seperti pada gambar 8 . 


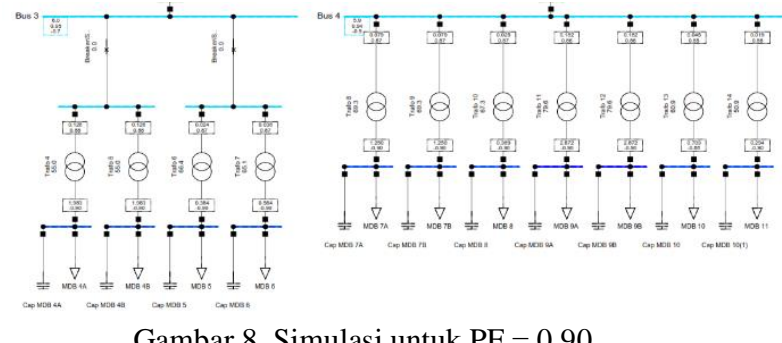

Gambar 8. Simulasi untuk $\mathrm{PF}=0,90$

E. Perbandingan Hasil Perhitungan dan Hasil Simulasi

a. Perbandingan Sebelum Perbaikan Faktor Daya

b. Tabel 6 adalah besar perbandingan antara nilai arus, daya aktif, dan besar faktor daya sebelum perbaikan faktor daya

Tabel 6. Perbandingan Hasil Sebelum Perbaikan Faktor Daya

\begin{tabular}{|c|c|c|c|c|c|c|c|}
\hline \multirow[b]{2}{*}{ No. } & \multirow[b]{2}{*}{ Lokasi } & \multicolumn{3}{|c|}{ Hasil Simulasi } & \multicolumn{3}{|c|}{ Data Perhitungan } \\
\hline & & $\begin{array}{c}\text { Arus } \\
\text { (A) }\end{array}$ & $\begin{array}{c}\mathbf{P} \\
(\mathbf{M W})\end{array}$ & $\mathbf{P F}$ & $\begin{array}{c}\text { Arus } \\
\text { (A) }\end{array}$ & $\begin{array}{c}\mathbf{P} \\
(\mathbf{M W})\end{array}$ & PF \\
\hline 1 & $\begin{array}{c}\text { MDB 4A } \\
\text { (Raw Mill } \\
1)\end{array}$ & 2735 & 1,138 & 0,68 & 2461 & 1,138 & 0,68 \\
\hline 2 & $\begin{array}{c}\text { MDB 4B } \\
\text { (Raw Mill } \\
\text { 2) }\end{array}$ & 2735 & 1,138 & 0,68 & 2461 & 1,138 & 0,68 \\
\hline 3 & $\begin{array}{c}\text { MDB 5 } \\
\text { (Raw Mill } \\
\text { 2) }\end{array}$ & 425 & 0,219 & 0,83 & 388 & 0,219 & 0,83 \\
\hline 4 & $\begin{array}{c}\text { MDB } 6 \\
\text { (Raw Mill } \\
\text { Transport) }\end{array}$ & 589 & 0,321 & 0,87 & 543 & 0,321 & 0,87 \\
\hline 5 & $\begin{array}{c}\text { MDB 7A } \\
\text { (Blending } \\
\text { Silo) }\end{array}$ & 1461 & 0,709 & 0,79 & 1320 & 0,709 & 0,79 \\
\hline 6 & $\begin{array}{l}\text { MDB 7B } \\
\text { (Blending } \\
\text { Silo) }\end{array}$ & 1461 & 0,709 & 0,79 & 1320 & 0,709 & 0,79 \\
\hline 7 & $\begin{array}{c}\text { MDB } 8 \\
(\text { Kiln })\end{array}$ & 421 & 0,22 & 0,84 & 385 & 0,22 & 0,84 \\
\hline 8 & $\begin{array}{c}\text { MDB 9A } \\
\text { (Clinker } \\
\text { Cooler) }\end{array}$ & 3213 & 1,615 & 0,82 & 2896 & 1,615 & 0,82 \\
\hline 9 & $\begin{array}{c}\text { MDB 9B } \\
\text { (Clinker } \\
\text { Cooler) }\end{array}$ & 3213 & 1,615 & 0,82 & 2896 & 1,615 & 0,82 \\
\hline 10 & $\begin{array}{l}\text { MDB } 10 \\
\text { (Coal Mill) }\end{array}$ & 862 & 0,392 & 0,74 & 779 & 0,392 & 0,74 \\
\hline 11 & $\begin{array}{c}\text { MDB } 11 \\
\text { (Precipitato } \\
\text { r) }\end{array}$ & 358 & 0,169 & 0,76 & 323 & 0,169 & 0,76 \\
\hline
\end{tabular}

c. Perbandingan Hasil untuk $\mathrm{PF}=0,90$

Tabel 7 adalah besar perbandingan antara nilai arus, daya aktif, dan besar faktor daya saat $\mathrm{PF}=0,90$.
Tabel 7. Perbandingan Hasil untuk $\mathrm{PF}=0,90$

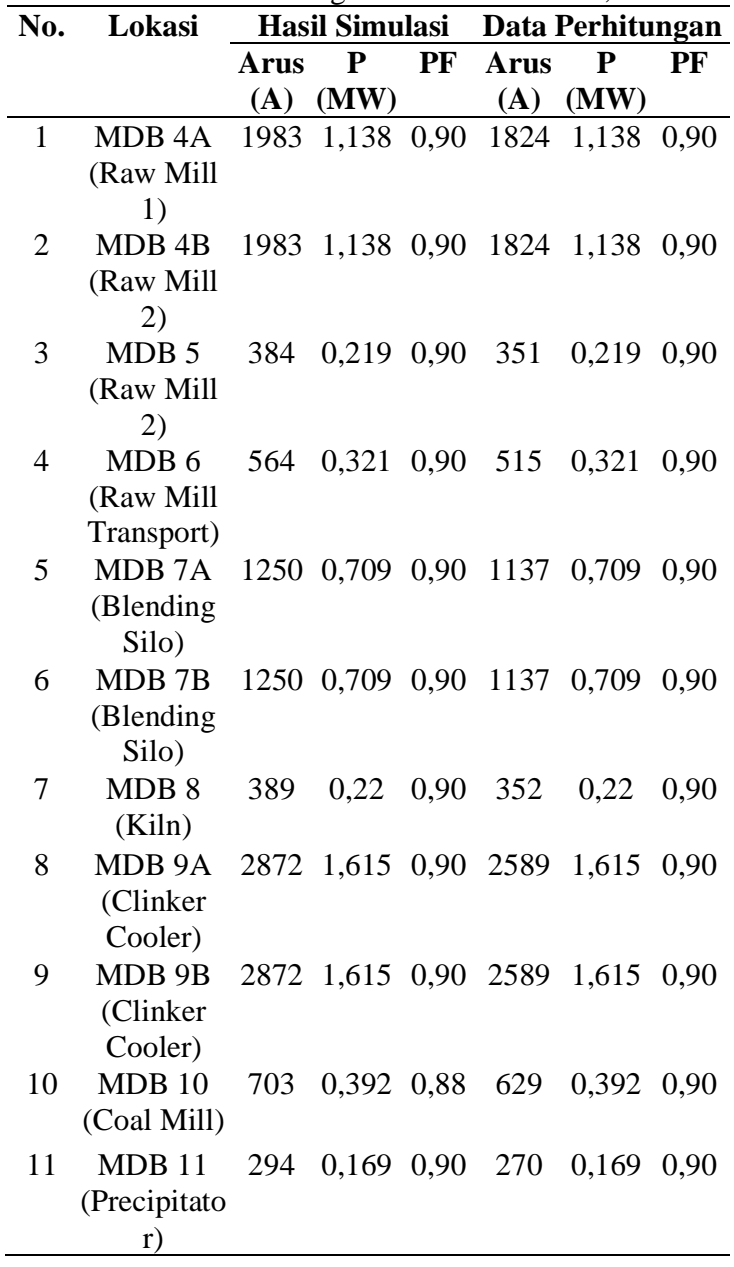

\section{V.KESIMPULAN}

Dari hasil penelitian yang dilaksanakan dapat ditarik beberapa kesimpulan, yaitu (1) Besar kompensasi daya reaktif $\left(\mathrm{Q}_{\mathrm{c}}\right)$ diperoleh berdasarkan selisih dari daya reaktif sebelum perbaikan faktor daya $\left(\mathrm{Q}_{\mathrm{b}}\right)$ dengan daya reaktif setelah perbaikan $\left(\mathrm{Q}_{\mathrm{t}}\right)$; (2) Besar kapasitor yang digunakan pada kompensasi daya reaktif berdasarkan nilai standar kapasitor yang ada di pasaran. Semakin besar nilai kompensasi daya reaktif yang ditimbulkan maka nilai kapasitor yang dibutuhkan dalam perbaikan faktor daya akan semakin besar; (3) Setelah faktor daya untuk tiap motor induksi 3 fasa diseragamkan nilai perbaikannya, maka besar arus beban menjadi semakin kecil dan nilai pasokan daya MVA menjadi semakin kecil.

\section{UCAPAN TERIMA KASIH}

Ucapan terima kasih penulis sampaikan kepada semua pihak yang telah ikut membantu kelancaran penulisan jurnal ini khususnya kepada : (1) Prof. Ir. Muhammad Anshar, M.Si., Ph.D.; (2) Dr. Ir. Hafsah Nirwana, S.T., M.T. ; (3) Sofyan, S.T., M.T. ; (4) 
Bakhtiar, S.T, M.T ; (5) Ruslan L, S.T, M.T. ; (6) Orang tua kami tercinta; (6) Teman-teman dan pihak-pihak lain yang tidak bisa penulis sebutkan satu persatu dalam jurnal ini.

\section{REFERENSI}

[1] Al Qahfi, Andi Sultan Alauddin, dan Rizqi Amalia Burhan. 2016. "Studi Pengaruh Kapasitor Shunt terhadap Susut Transmisi Sistem Interkoneksi SULSELRABAR". Skripsi. Makassar : Politeknik Negeri Ujung Pandang.

[2] Edi Sunarwi A. 2018. "Analisis Kompensasi Reaktif Terhadap Motor Induksi 3 phasa”. Skripsi. Makassar : Politeknik Negeri Ujung Pandang.

[3] I Nyoman Bagia, dan I Made Parsa. 2018. Motor-Motor Listrik. Kupang : CV. Rasi Terbit

[4] Alvon Satria, dan Edy Ervianto. 2017. Perbaikan Faktor Daya Menggunakan Motor Sinkron Dengan Metode Fuzzy Logic Control. Jurnal Ilmu Pendidikan, (Online) (https://jom.unri.ac.id/index.php/JOMFTEKNI K/article/view/14954, diakses 19 Oktober 2018)

[5] Rahardjo, Yadi Yunus. 2010. Perbaikan Faktor Daya Motor Induksi 3 Fase. Seminar Nasional VI SDM Teknologi Nuklir, (Online) (http://papers.sttn-

batan.ac.id/prosiding/2010/54.pdf, diakses 20 November 2018)

[6] Sonni, Muhammad Nasir. 2010. Perbandingan Antara Kompensasi Daya Reaktif Terpusat Dengan Kompensasi Daya Reaktif Terdistribusi Bagi Perbaikan Kestabilan Tegangan Pada Sistem Kelistrikan Sumbar - Riau. Jurnal Ilmu Pendidikan,(Online)(http://repo.unand.ac.id/34 37/1/48_-_54_NASIR_SONNI.docx , diakses 21 November 2018). 